\title{
Integrated electrochemical biosensor based on algal metabolism for water toxicity analysis
}

A. Tsopela ${ }^{1,2}$, A. Lale ${ }^{1,2}$, E. Vanhove ${ }^{1,2}$, O. Reynes ${ }^{3}$, I.Séguy ${ }^{1,2}$, P. Temple-Boyer ${ }^{1,2}$, P. Juneau ${ }^{4}$, R. Izquierdo 4 , J. Launay ${ }^{1,2}$

${ }^{1}$ CNRS, LAAS, 7 avenue du colonel Roche, F-31400 Toulouse, France

${ }^{2}$ Université de Toulouse, UPS, LAAS, F-31400 Toulouse, France

${ }^{3}$ Université de Toulouse, UPS, LGC, 31062 Toulouse, France

${ }^{4}$ Université du Québec à Montréal ; 201 Président Kennedy ; Montréal, Canada

\section{Abstract}

An autonomous electrochemical biosensor with three electrodes integrated on the same silicon chip dedicated to the detection of herbicides in water was fabricated by means of siliconbased microfabrication technology. Platinum (Pt), platinum black (Pt Bl), tungsten/tungsten oxide $\left(\mathrm{W} / \mathrm{WO}_{3}\right)$ and iridium oxide $\left(\mathrm{Pt} / \mathrm{IrO}_{2}\right)$ working ultramicroelectrodes were developed. $\mathrm{Ag} / \mathrm{AgCl}$ and $\mathrm{Pt}$ electrodes were used as reference and counter integrated electrodes respectively. Physical vapor deposition (PVD) and electrodeposition were used for thin film deposition. The ultramicroelectrodes were employed for the detection of $\mathrm{O}_{2}, \mathrm{H}_{2} \mathrm{O}_{2}$ and $\mathrm{pH}$ related ions $\mathrm{H}_{3} \mathrm{O}^{+} / \mathrm{OH}^{-}$, species taking part in photosynthetic and metabolic activities of algae. By measuring the variations in consumption-production rates of these electroactive species by algae, the quantity of herbicides present at trace level in the solution can be estimated. Fabricated ultramicroelectrodes were electrochemically characterized and calibrated. Pt Black 
ultramicroelectrodes exhibited the greatest sensitivity regarding $\mathrm{O}_{2}$ and $\mathrm{H}_{2} \mathrm{O}_{2}$ detection while $\mathrm{Pt} / \mathrm{IrO}_{2}$ ultramicroelectrodes were more sensitive for $\mathrm{pH}$ measurement compared to $\mathrm{W} / \mathrm{WO}_{3}$ ultramicroelectrodes for $\mathrm{pH}$ measurement. Bioassays were then conducted to detect traces of Diuron herbicide in water samples by evaluating disturbances in photosynthetic and metabolic activities of algae caused by this herbicide.

Keywords: ultramicroelectrodes; oxygen; hydrogen peroxide; $\mathrm{pH}$ measurement; algal metabolism; pesticides detection 


\section{Introduction}

Water quality assessment has been an issue of particular concern over the past few years and is actually generating major interest. Contamination of water resources brought about by agricultural and industrial practices can pose possible threats and have a long-term impact on the environment and all living organisms. Pesticides are frequently employed in agriculture to protect crops and control non-crops and can easily leach from the soil in underground water supply and be often detected in rivers, lakes and later in consumption water (Barbash et al., 2001). It is therefore a major challenge to rapidly detect contamination by monitoring the quantities of different toxicants present in water.

Conventional analysis methods like gas (Schellin et al., 2004) and liquid (Jáuregui et al., 1997) chromatography performed in highly equipped laboratories do still provide the most accurate and sensitive means of detecting water contamination but they encounter considerable limitations as they are expensive and time consuming (Eltzov and Marks, 2011). Electrochemical detection systems are a potential alternative to these methods as they are easily miniaturized and portable enabling on-site analysis and providing rapid, real-time feedback information on the presence of pollutants (Lagarde and Jaffrezic-Renault, 2011; Grieshaber et al., 2008; Li et al., 2013). More specifically, lab on chip based, electrochemical biosensors meet the requirement for a rapid, cost-effective, accurate and sensitive analytical system and give information on water quality by detecting wide range of chemical species (Jang et al., 2011). They convert a biochemical phenomenon into a detectable and measurable electrical signal that is proportional to the analyte concentration and provide an early indication by sorting the samples needed to be further analyzed by conventional techniques.

Electrochemical biosensors can be amperometric, potentiometric and conductometric.

The operating principle of amperometric biosensors lies in applying a potential and 
recording the current corresponding to oxidation and reduction of electroactive species on electrode surface. Current variations result from variations in consumption-production rates of electroactive species and reflect the biochemical phenomenon taking place (Ben-Yoav et al., 2009). Amperometric biosensors have been widely used for the oxygen monitoring in wastewaters (Chan et al., 2000), detection of organophosphates (Mulchandani et al., 2001), phenols (Mulchandani et al., 2005), cyanide (Ikebukuro et al., 1996) and heavy metal ions (Lehmann et al., 2000).

Potentiometric biosensors are designed to measure the difference in potential between working electrode and a stable reference electrode with no current flowing through the system (Lagarde and Jaffrezic-Renault, 2011). Potential values are then correlated to the concentration of the analyte (Lei et al., 2006). Although $\mathrm{pH}$ electrodes have been widely used for detection of pesticides in agriculture (Mulchandani et al., 2001; Gaberlein et al., 2000), other ion selective electrodes, such as chloride ion selective electrode, have also generated major interest in wastewater treatment domain (Han, 2002).

Conductometric biosensors record variations in conductivity of the electrolyte containing charged species in contact with the electrode (Lagarde and Jaffrezic-Renault, 2011). These variations result from the production or consumption of charged species during different reactions and can therefore indicate a biological process taking place (Lawrence and Moores, 1972; Jaffrezic-Renault and Dzyadevych, 2008). They have found various applications in environmental monitoring for detection of heavy metal ions and pesticides (Chouteau et al., 2004; Chouteau et al., 2005).

As far as biological recognition elements are concerned, algae are often used in biochemistry for trace detection of environmental toxic compounds as they are sensitive to changes in their environment induced by the presence of toxicants and can therefore provide information on toxic effect of pollutants on living organisms (Giardi and Pace, 2005; Brayner et al., 2011; MorenoGarrido, 2008; Carrilho et al., 2003). Due to their high sensitivity to toxic substances, even 
lower detection limits (LOD) can be reached (Brayner et al., 2011). Microalgae and photosynthetic cyanobacteria are used in biosensors industry as they are capable of providing information on pollution levels based on modifications in photosynthetic or metabolic activity (Kasai and Hatakeyama, 1993; Lagarde and Jaffrezic-Renault, 2011). Monitoring of species such as oxygen, hydrogen peroxide and $\mathrm{pH}$ related ions that participate in algae's metabolism and photosynthesis can indicate the presence of herbicides. For instance, amperometric microalgae sensors are designed to monitor photosynthetic oxygen production and can therefore indicate pollutant related photosynthetic activity inhibition (Pandard and Rawson, 1993). Furthermore, hydrogen peroxide, the concentration of which is related to potential stress exerted on algae, could be useful indicator of the presence of herbicides. As reported by Mittler (Mittler, 2002), reactive oxygen species (ROS) can be stress indicators and signals for defense pathways activation. Different types of stress (pathogens, extreme temperatures, light, heavy metals, salt, pollutants) can cause metabolic disruptions resulting in an increase in the production of ROS (Mittler et al., 2004). Along with $\mathrm{O}_{2}$ and $\mathrm{H}_{2} \mathrm{O}_{2}$, pH monitoring can also provide information on metabolic activity modifications induced by herbicides and other inhibitors based on changes in medium basification and acidification rates (Schubnell et al., 1999).

As a matter of fact, different sensors have been developed for the detection of the species mentioned above, viewed as indicators of water pollution $\left(\mathrm{O}_{2}, \mathrm{H}_{2} \mathrm{O}_{2}, \mathrm{H}_{3} \mathrm{O}^{+} / \mathrm{OH}^{-}\right.$ions $)$. Two basic detection methods, amperometry and potentiometry have been discussed and various electrode materials have been mentioned.

As far as oxygen monitoring is concerned, noble metals ( $\mathrm{Pt}$ or $\mathrm{Au}$ ) are primarily used in literature as working electrode materials so that the electrode surface does not participate in the chemical reaction (Lee et al., 2007). Platinum is the most suitable candidate for oxygen detection as it is physically stable (Zhang and Wilson, 1993), mechanically robust (Ben-Amor et al., 2013) and compared to gold and other metals is the best electrocatalyst for the oxygen reduction reaction (Maja N. Desic, 2005). Platinum microdiscs (Sosna et al., 2007) and array of platinum 
microelectrodes (Wittkampf et al., 1997) have been employed as dissolved oxygen sensors in environmental monitoring. Different techniques have been followed to enhance sensitivity by increasing electro-active surface area and porosity of platinum electrodes and therefore enhancing mass transport of species towards electrode surface (Qiang et al., 2010; Lee and Park, 2011). Although platinum is the most commonly applied material in oxygen sensors, gold electrodes have been designed to measure dissolved oxygen in environmental samples (Liu et al., 2007), bacterial films (Lee et al., 2007) or during cell culture (Pereira Rodrigues et al., 2008). Carbon nanotubes integrated on a screen-printed algal biosensor have also been used to detect oxygen produced by algae (Shitanda et al., 2009).

As already stated, hydrogen peroxide is an essential species to monitor as it is taking part in various biological processes (Li et al., 2013). Gold (Brett et al., 1997), platinum(Zhang and Wilson, 1993; Yokoyama et al., 1997), carbon based (Cho et al., 2010; Nowall and Kuhr, 1997), enzyme modified (Ruzgas et al., 1996) and Prussian Blue modified (Karyakin et al., 2009) electrodes are situated in the main stream of research interest towards suitable working electrode materials for the detection of $\mathrm{H}_{2} \mathrm{O}_{2}$. Platinum is still the preferred option as it provides a high catalytic surface for $\mathrm{H}_{2} \mathrm{O}_{2}$ oxidation (Arbault et al., 1995) and it is even possible to increase active surface area of the electrodes by platinization. Indeed, sensors with platinized working electrodes yield greater sensitivity due to their nanoscale structure (Vaddiraju et al., 2010) and the large number of electroactive sites that facilitates electron transfer ( $\mathrm{Li}$ et al., 2013). Furthermore, on platinum black (Pt $\mathrm{Bl}$ ) microelectrodes, $\mathrm{H}_{2} \mathrm{O}_{2}$ oxidation is taking place at a lower potential compared to bare Pt electrodes, minimizing interferences induced by other electroactive species (Arbault et al., 1995). Platinum black microelectrodes have been widely used to study ROS species released during cellular oxidative bursts (Li et al., 2013) and monitor the production of $\mathrm{H}_{2} \mathrm{O}_{2}$ by mitochondria during aerobic metabolism (Ben-Amor et al., 2013). They have also found various applications as amperometric glucose sensors (De Corcuera et al., 2005). 
Potentiometry is widely applied for $\mathrm{pH}$ monitoring and glass membrane electrodes are commonly used. However, glass fragility and size limitation impede in situ measurement in complex configurations and mediums (Ruffien-Ciszak et al., 2008; Huang et al., 2011) giving way to metal/metal oxide based $\mathrm{pH}$ sensors that are easily miniaturized and provide a welldefined metal/metal oxide interface (Daomin Zhou, 2008). More specifically, iridium oxide films can be formed by various physical and chemical methods (Ges et al., 2005) and exhibit many advantages among which high $\mathrm{pH}$ sensitivity, biocompatibility, chemical stability and fast response time (Daomin Zhou, 2008; Marzouk et al., 1998). $\mathrm{IrO}_{2}$ films have therefore found applications in cell metabolism monitoring in cell culture volumes (Ges et al., 2005) and microenvironmental studies (Bezbaruah and Zhang, 2002). Tungsten/tungsten oxide sensors represent another attractive alternative for $\mathrm{pH}$ monitoring as tungsten is cheaper compared to other metals such as Pt or Au. Additionally, stable tungsten oxides can be easily formed by electrochemical oxidation of the metal at low potential (Ruffien-Ciszak et al., 2008). W/WO 3 sensors have been developed for skin pH monitoring (Ruffien-Ciszak et al., 2008), determination of extracellular $\mathrm{pH}$ values for cultured cells (Yamamoto et al., 2003) and pH measurement of environmental water samples (Dimitrakopoulos et al., 1998).

Thus, elaboration of detection materials and analytical methods led to the development of different systems applied for detection of water pollution. In this study, an autonomous fully integrated three-electrode electrochemical microsystem is developed by means of microfabrication technology on a silicon chip. The performance of the microsystem is evaluated through electrochemical characterization and calibration is performed by amperometric and potentiometric methods for the three species of interest: dissolved oxygen $\left(\mathrm{O}_{2}\right)$, hydrogen peroxide $\left(\mathrm{H}_{2} \mathrm{O}_{2}\right)$ and $\mathrm{pH}$ related ions $\left(\mathrm{H}_{3} \mathrm{O}^{+} / \mathrm{OH}^{-}\right)$. The electrochemical microsystem is further used in bioassays, serving as screening prior to lab-analysis, to detect traces of toxicants in water samples by evaluating their effect on a biological sensing element, such as algae. Pollution level was estimated by measuring disturbances in photosynthetic and metabolic activities of algae 
caused by herbicides. These disturbances are represented by variations in consumptionproduction rates of the three electro-active species (dissolved oxygen, hydrogen peroxide and $\mathrm{pH}$ related ions) by algae and could therefore be detected by the electrochemical microsensor. A variation of oxygen production during algal photosynthesis is evidenced in the presence of Diuron herbicide.

\section{Experimental}

\subsection{Electrode materials and configuration}

Electrochemical microcells designed for this work consist of three integrated electrodes (working, reference, and counter electrodes) on the same silicon chip (Christophe et al., 2013). Working electrode materials were determined according to previously mentioned electro-active species needed to be detected. Platinum and functionalized Platinum Black (Pt Bl) working electrodes were fabricated for $\mathrm{H}_{2} \mathrm{O}_{2}$ and dissolved $\mathrm{O}_{2}$ measurements whereas tungsten/tungsten oxide $\left(\mathrm{W} / \mathrm{WO}_{3}\right)$ and iridium oxide $\left(\mathrm{Pt} / \mathrm{IrO}_{2}\right)$ electrodes were used for $\mathrm{pH}$ monitoring. The autonomous, miniaturized electrochemical cell was completed by integrating a platinum counter electrode and a silver based electrode in the structure. The latter was further electrochemically oxidized to form the $\mathrm{Ag} / \mathrm{AgCl}$ reference electrode. In order to determine the arrangement and form of the three integrated electrodes, different electrode configurations were patterned; parallel and concentric arrangements were tested. For concentric arrangement, working electrode is encircled by the reference and counter electrodes that have a ring shape while for parallel arrangement, all electrodes are placed in parallel with reference electrode placed in the middle of the structure to reduce ohmic drop. Both single ultramicroelectrodes and ultramicroelectrode arrays were evaluated in terms of detection properties. In this way, favorable properties of ultramicroelectrodes and planar array configurations were used to enhance the efficiency of the sensors. Dimensions and distance between electrodes in the array were determined so that diffusion profiles of adjacent electrodes will not overlap. 


\subsection{Fabrication of the electrochemical microcells}

Electrochemical microcells were fabricated on a thermally oxidized silicon wafer $\left(\mathrm{SiO}_{2}\right)$ (oxide layer thickness: $\sim 1 \mu \mathrm{m}$ ). All thin metal layers were evaporated on the oxidized silicon substrate (Figure 2a) and conventional photolithography followed by lift-off technique was conducted in order to obtain metal patterns. Platinum (Pt) $(150 \mathrm{~nm})$ and tungsten $(\mathrm{W})(500 \mathrm{~nm})$ layers correspond to working electrodes while silver $(\mathrm{Ag})$ layer $(400 \mathrm{~nm})$ represents the future reference electrode. Platinum $(\mathrm{Pt})(150 \mathrm{~nm})$ also serves as the counter electrode. The underlying titanium (Ti) layer $(20 \mathrm{~nm})$ assures adhesion of platinum on $\mathrm{SiO}_{2}$ substrate. Silver was deposited on a platinum layer, which in this case serves as a barrier layer, in order to avoid diffusion of titanium atoms in the silver layer. All layer thicknesses were selected so that no mechanical stress is exerted on the silicon wafer. Following the development of all metal layers, electrode's active surface area needed to be precisely defined as it will be later used to correlate current intensity recorded to the quantity of species to be detected. Low temperature Inductively Coupled Plasma Chemical Vapour Deposition (ICP-CVD) was conducted for the deposition of high quality silicon nitride $\left(\mathrm{Si}_{3} \mathrm{~N}_{4}\right)$ insulation layer $(100 \mathrm{~nm})$ (Figure 1a). ICP-CVD process yields conformal deposition that enables perfect covering of the whole structure -even the lateral parts of metal layers. However, in order to enable patterning of a conformal coating, a specific double layer lift-off process has been developed and the thickness of the $\mathrm{Si}_{3} \mathrm{~N}_{4}$ film was optimized accordingly (Vanhove et al., 2013). This insulation layer also contributes to long-term stability of electrochemical microcells in contrast to organic insulation layers that do not provide sufficient stability through time in complex, corrosive mediums (Vanhove et al., 2013). After fabrication, devices were diced and attached on a printed circuit board (PCB). Wedge bonding was subsequently carried out to complete packaging procedure and wire bonds were covered in a silicon glob-top to assure mechanical protection and avoid electrical short circuit (Figure 1b). 


\subsection{Surface functionalization of ultramicroelectrodes}

In order to attain high sensitivity of platinum working electrodes, porosity and surface area were enhanced by forming "black platinum" electrodes. Platinization procedure was carried out by reducing a solution of hexachloroplatinic acid (32 $\mathrm{mM}$ in phosphate buffer solution) which contains lead acetate $(1.23 \mathrm{mM})$ at $-60 \mathrm{mV}$ versus $\mathrm{Ag} / \mathrm{AgCl} / \mathrm{KCl}_{\text {sat }}$ (Ben-Amor et al., 2013). The amount of Pt deposited was controlled by the coulometric charge versus time plots recorded during platinization so that a nanostructured surface will be obtained. Platinization charge deposited on single Pt ultramicroelectrodes $(\mathrm{d}=50 \mu \mathrm{m})$ was $0.5 \mu \mathrm{C} . \mu \mathrm{m}^{-2}$ compared to 0.25 $\mu \mathrm{C} . \mu \mathrm{m}^{-2}$ on the arrays of Pt ultramicroelectrodes (25 disks of $10 \mu \mathrm{m}$ diameter).

Regarding $\mathrm{pH}$ electrodes, tungsten $\mathrm{W}$ surface was oxidized to form a $\mathrm{WO}_{3}$ film by cyclic voltammetry in a $2 \mathrm{M} \mathrm{H}_{2} \mathrm{SO}_{4}$ solution, from +1.0 to $+2.0 \mathrm{~V}$ vs $\mathrm{Ag} / \mathrm{AgCl} / \mathrm{KCl}_{\text {sat }}$, at the scan rate of $20 \mathrm{mV} . \mathrm{s}^{-1}$ for 20 cycles (Yamamoto et al., 2003). For the deposition of $\mathrm{IrO}_{2}$ on Pt electrodes, an iridium tetrachloride based solution was prepared as described elsewhere (Marzouk, 2003). A constant potential (0.6 V/ECS) was applied and the duration of the deposition was indicated by the total charge transferred $(0.5$ C.cm²) (Ges et al., 2005).

In order to form the $\mathrm{Ag} / \mathrm{AgCl}$ reference electrode and obtain a fully integrated electrochemical cell, Ag surface was electrochemically oxidized. Silver surface was first examined by conducting cyclic voltammetry in acidified potassium nitrate $\left(\mathrm{KNO}_{3}\right)$ solution of 0.1 M. The electrode was then oxidized in $10^{-2} \mathrm{M}$ potassium chloride solution $(\mathrm{KCl})$ by linear sweep voltammetry within the potential range of $0.1-0.25 \mathrm{~V} / \mathrm{ECS}$ and a low scan rate of $1 \mathrm{mV} . \mathrm{s}^{-1}$ which yields stable and homogeneous $\mathrm{Ag} / \mathrm{AgCl}$ structure (Christophe et al., 2013). Indeed, higher scan rates could result in porous layers and electroactive species trapped between pores induce changes in reference electrode's potential (Christophe et al., 2013).

\subsection{Electrochemical characterization and calibration}

All electrochemical experiments were conducted using a potentiostat (VMP3, BioLogic) 
with a low-current option controlled by EC-Lab software, at room temperature.

Cyclic voltammetry in a zero oxygen $0.5 \mathrm{M} \mathrm{H}_{2} \mathrm{SO}_{4}$ solution was conducted to characterize the quality of fabricated $\mathrm{Pt}$ and $\mathrm{Pt} \mathrm{B}$ l electrodes. Potential range scanned was -0.2 to $+1.1 \mathrm{~V}$ vs $\mathrm{Ag} / \mathrm{AgCl} / \mathrm{KCl}_{\text {sat }}$ at a scan rate of $100 \mathrm{mV}$. Material properties were tested in order to validate that all thin layers developed by microfabrication technology gave results similar to the ones obtained with bulk materials.

For Pt and Pt Bl working electrodes, active surface area was determined by linear sweep voltammetry in solutions of potassium hexacyanoferrate (II) trihydrate $(10 \mathrm{mM})$ in $0.1 \mathrm{M} \mathrm{KCl}$ used as a supporting electrolyte.

Calibration curves for $\mathrm{H}_{2} \mathrm{O}_{2}$ measurements were then obtained by recording current responses to different concentrations. $\mathrm{pH}$ sensors calibration was performed by monitoring the potential of the two metal oxide electrodes in solutions of different $\mathrm{pH}$ through open circuit potential $(\mathrm{OCP})$ mode. $\mathrm{O}_{2}$ sensors performance was pre-validated in saturated in oxygen and zero oxygen $\mathrm{CaCl}_{2}(0.1 \mathrm{M})$ solutions by comparing current values obtained.

\subsection{Bioassays}

As far as bioassays are concerned, green micro algae Chlamydomonas reinhardtii (CC-125) were cultivated at $25^{\circ} \mathrm{C}$ with time regulated light/dark (16h/8h) cycles in High Salt Medium (HSM) (N Sueoka, 1967). The same solution was used through all our tests. The main goal of this study being to determine the relation between the change in metabolic activities of algae and the presence of herbicides, measurements were conducted in model HSM solution in order to eliminate possible interferences found in real water samples. Nevertheless, for final application, we plan to validate this concept in consumption water obtained from groundwater, rivers or lakes). Growth parameters were controlled so that algae's growth rate is constantly kept at the exponential phase. Considering that the quantity of species produced or consumed depends on the number of cells in the solution, initial algal solutions were centrifuged to obtain a 5-fold 
density increase, in order to yield the maximum possible signal. Concentration of cells per mL of solution was always kept constant through different experiments and was measured by Multisizer Coulter Counter (Beckman Coulter). Bioassays using the fabricated electrochemical microsensors were performed in the dense algal solutions and current evolution was observed during light and dark periods in the presence and absence of Diuron (3(3,4-dichlorophenyl)-1,1dimethylurea) herbicide, the toxic chemical to be detected. Chronoamperometry was conducted and the potential applied corresponds to the $\mathrm{O}_{2}$ reduction potential which was estimated through cyclic voltammetry at $-0.7 \mathrm{~V}$ vs integrated $\mathrm{Ag} / \mathrm{AgCl}$.

All reagents were purchased from Sigma-Aldrich.

\section{Results and discussion}

3.1 Electrochemical characterization - calibration of ultramicroelectrodes

The voltammograms obtained for fabricated $\mathrm{Pt}$ and $\mathrm{Pt} \mathrm{Bl}$ thin film electrodes in $0.5 \mathrm{M} \mathrm{H}_{2} \mathrm{SO}_{4}$ (voltammogramms not shown) presented peaks related to the formation and reduction of platinum oxides as well as the electrosorption and electrodesorption of protons indicating a behaviour similar to the one of Pt polycrystalline bulk material (Tilak et al., 1973). The radius of fabricated single and array $\mathrm{Pt}$ and $\mathrm{Pt} \mathrm{B}$ l electrodes was then evaluated in $\mathrm{Fe}(\mathrm{CN}) 6^{4-}$ solution and compared to the dimensions initially designed. The value was determined through the theoretical equation relating $\mathrm{I}_{\text {lim }}$ current (value of the oxidation plateau) to the radius of the electrode (Equations 1 and 2) (Saito, 1968). Equation 2 is given for an array of microdisk electrodes widely spaced where there is no overlapping of diffusion layers and $\mathrm{I}_{\text {lim }}$ represents the sum of currents obtained for each ultramicroelectrode as they are connected in parallel. As expected, platinum black porous structure yielded well-defined oxidation plateaus and steeper waves indicating rapid electron transfer reactions. Platinization induces a 6-fold increase in electrode's Ilim value. 


$$
\begin{array}{ll}
I_{\text {lim }}=4 n F D C r & \text { Equation 1 } \\
I_{\text {lim }}=4 n F D C r z & \text { Equation 2 }
\end{array}
$$

Where $\mathrm{F}$ is the Faraday constant $\left(\mathrm{F}=96500 \mathrm{C} \cdot \mathrm{mol}^{-1}\right), \mathrm{n}$ is the number of electrons exchanged per mole $(\mathrm{n}=1), \mathrm{C}$ is $\mathrm{Fe}(\mathrm{CN}) 6^{4-}$ ion concentration $(0.01 \mathrm{M}), \mathrm{D}$ represents the diffusion coefficient $\left(6.3 \times 10^{-6} \mathrm{~cm}^{2} . \mathrm{s}^{-1}\right)$ (Konopka and McDuffie, 1970) and $\mathrm{z}$ is the number of electrodes in the array.

Regarding Ag electrode it is important to note that the obtained $\mathrm{Ag} / \mathrm{AgCl}$ is a quasi-reference electrode as it is in direct contact with the examined solution without any internal electrolyte (Simonis et al., 2004). Quasi-reference electrode's stability was evaluated in $0.01 \mathrm{M} \mathrm{KCl}$ solution. $\mathrm{Ag} / \mathrm{AgCl}$ electrode's potential compared to external $\mathrm{Ag} / \mathrm{AgCl} / \mathrm{KCl}_{\text {sat }}$ electrode was plotted versus time (results not shown). Potential deviation in time was estimated around 0.16 $\mu \mathrm{V} . \mathrm{s}^{-1}$, value that is an acceptable for the present application given the fact that short-time measurements are conducted.

Following validation of electrochemical performance of different electrode materials, microelectrochemical cells were used to detect electroactive species of interest $\left(\mathrm{H}_{2} \mathrm{O}_{2}, \mathrm{O}_{2}\right.$, pH related ions $\left.\mathrm{H}_{3} \mathrm{O}^{+} / \mathrm{OH}^{-}\right)$.

$\mathrm{H}_{2} \mathrm{O}_{2}$ detection was firstly performed by following current increase after successive injections of $\mathrm{H}_{2} \mathrm{O}_{2}$ in PBS $(10 \mathrm{mM})$ solution (Figure 2a). Concentration range tested was between $10 \mathrm{nM}$ and $10 \mu \mathrm{M}$ so that it can be verified that the detection of low $\mathrm{H}_{2} \mathrm{O}_{2}$ quantities (range of interest in biological applications) is feasible. An anodic potential of $0.6 \mathrm{~V}$ and $0.3 \mathrm{~V}$ vs $\mathrm{Ag} / \mathrm{AgCl} / \mathrm{KCl}_{\text {sat }}$ was applied to initiate the oxidation of $\mathrm{H}_{2} \mathrm{O}_{2}$ present in the solution for Pt and Pt Bl electrodes respectively. The potential applied corresponds to the plateau potential of the oxidation wave determined by cyclic voltammetry in $10 \mathrm{mM} \mathrm{H} \mathrm{H}_{2}$ solution in PBS. The lower 
potential value applied for $\mathrm{Pt} \mathrm{Bl}$ compared to the one applied for Pt electrodes is ascribed to electrocatalytic activity of platinum black towards $\mathrm{H}_{2} \mathrm{O}_{2}$ reactions (Arbault et al., 1995). Calibration curves for $\mathrm{H}_{2} \mathrm{O}_{2}$ microsensors were obtained by plotting current increase recorded for each injection (Figure 2b). Platinum and platinum black single electrodes and arrays were compared in terms of sensitivity and limits of detection (LOD).

Linear response was observed through the entire concentration range tested $\left(R^{2} \geq 0.99\right)$ for all $\mathrm{Pt}$ and $\mathrm{Pt} \mathrm{Bl}$ single electrodes and arrays. Black platinum electrode arrays exhibited the greatest sensitivity for $\mathrm{H}_{2} \mathrm{O}_{2}$ detection with a slope of $17 \mathrm{pA} \cdot \mathrm{mm}^{-2} \cdot \mathrm{nM}^{-1}$ and a limit of detection of $10 \mathrm{nM}$. As a matter of fact, arrays hold the advantages of microelectrodes while generating a higher current signal. Their high signal-to-noise ratio combined with the high electrocatalytic activity of platinum black surface lead to enhanced electrode performance regarding detection properties, detection limits and sensitivities. Pl Bl single electrodes also yielded higher sensitivity than Pt electrodes with a slope of $12.4 \mathrm{pA} \cdot \mathrm{mm}^{-2} \cdot \mathrm{nM}^{-1}$ but 1.4 times lower than the one provided by $\mathrm{Pt} \mathrm{Bl}$ arrays.

Prior to validation of $\mathrm{O}_{2}$ microsensors in algal solutions it was important to verify that the sensor yields a response correlated to $\mathrm{O}_{2}$ concentration. The electrode potential was therefore set at $-0.7 \mathrm{~V}$ vs $\mathrm{Ag} / \mathrm{AgCl} / \mathrm{KCl}_{\text {sat}}$, (potential corresponding to the plateau value of oxygen reduction current) and output current was recorded for a saturated and a zero oxygen $\mathrm{CaCl}_{2}(0.1 \mathrm{M})$ solution at $22{ }^{\circ} \mathrm{C}$. As expected, $\mathrm{O}_{2}$ concentration variation induces a variation in current intensity generated by the $\mathrm{O}_{2}$ reduction reaction on platinum or platinum black electrodes (results not shown).

Overall, $\mathrm{Pt} \mathrm{Bl}$ ultra-microelectrode arrays present the greatest sensitivity for $\mathrm{O}_{2}$ and $\mathrm{H}_{2} \mathrm{O}_{2}$ reactions due to the electrocatalytic activity of platinum black towards these reactions (Arbault et al., 1995; Ben-Amor et al., 2014). Indeed, Pt Bl electrodes exhibit increased electro-active surface area and porosity compared to platinum electrodes and therefore enhanced mass 
transport of species towards electrode surface. Their nanoscale structure (Vaddiraju et al., 2010) and large number of electroactive sites enhance electron transfer (Li et al., 2013).

$\mathrm{pH}$ measurements were conducted by the open circuit potential technique for calibration of $\mathrm{W} / \mathrm{WO}_{3}$ and $\mathrm{Pt} / \mathrm{IrO}_{2}$ electrodes. Equilibrium potential was recorded for different $\mathrm{pH}$ solutions. This potential is given by Nernst equation and for metal/metal oxide electrodes depends only on the $\mathrm{pH}$ of the solution. As pointed out by the graph in Figure 3a, the $\mathrm{Pt} / \mathrm{IrO}_{2} \mathrm{pH}$ sensor presented no hysteresis. Both electrodes demonstrated an almost linear response over a wide $\mathrm{pH}$ range (2.0-12.0). The sensitivity of $\mathrm{Pt} / \mathrm{IrO}_{2}$ electrode $(60 \mathrm{mV} / \mathrm{pH})$ was superior to that of $\mathrm{W} / \mathrm{WO}_{3}$ electrode $(42 \mathrm{mV} / \mathrm{pH})$ (Figure $3 \mathrm{~b}$ ). $\mathrm{Pt} / \mathrm{IrO}_{2}$ exhibits a supra-Nernstian response due to the oxidation states present on the surface as already reported in literature (Kim and Yang, 2014; Olthuis et al., 1990). On the other hand, $\mathrm{W} / \mathrm{WO}_{3}$ electrodes demonstrate a sub-Nernstian response that can be due to defects in the metal-metal oxide interface produced through oxidation of the tungsten layer. What is more, if the oxidation of the tungsten layer deposited through PVD is not optimized, native tungsten oxides such as $\mathrm{WO}_{2}$ or $\mathrm{W}_{2} \mathrm{O}_{5}$ (Pasti et al., 2012) can be also created on the surface along with $\mathrm{WO}_{3}$ which leads to a lower sensitivity of the final layer. In order to improve characteristics of the $\mathrm{W} / \mathrm{WO}_{3}$ sensors, optimization of the electrooxidation procedure is in progress.

\subsection{Bioassays}

Special emphasis was placed on $\mathrm{O}_{2}$ detection as it was considered to be the main pollution indicator, given the fact that $\mathrm{O}_{2}$ evolution reflects photosynthetic activity of algae and that it is largely altered by pollutants' existence. Photosystem II (PSII) is a complex located in the thylakoid membranes of algae where light energy is used to produce oxygen from water oxidation through a series of electron transfer reactions during photosynthesis (Varsamis et al., 2008; Giardi and Pace, 2005). Urea-based pollutants, such as Diuron, disrupt the electron flow in PSII because of their high-affinity binding to the PSII complex (Pfister et al., 1981). They bind 
to the D1 protein of PSII within its plastoquinone QB binding pocket blocking photosynthetic electron transport and therefore inhibiting $\mathrm{O}_{2}$ production (Tischer and Strotmann, 1977).

At first, the performance of the sensor for $\mathrm{O}_{2}$ detection was evaluated with algae in the absence of toxicants in order to demonstrate the relationship between the photosynthetic activity and the current signal measured. Light and dark periods were therefore altered to obtain equal periods of daylight illumination and darkness and current variations were recorded through chronoamperometry. Under illumination, amperometric responses recorded, exhibited an increase in the oxygen reduction current due to photosynthesis. The decrease was evident when light was turned off as a result of respiration process during which algae consume oxygen and produce $\mathrm{CO}_{2}$ (Figure 4). Initial duration of light and dark cycles was six minutes. We then reduced cycle duration to two minutes in order to validate that similar response is obtained even by applying shorter time intervals. It is important to notice that the change in current evolution is immediately evident when light is switched on and off.

Variations in photosynthetic activity of algae were then determined in presence of Diuron herbicide (Figure 5). As ethanol 70\% is the solvent used to prepare Diuron solutions, its volume was kept constant through different injections to prevent solvent influence on algal response. Current evolution through respiration and photosynthesis with and without Diuron is presented in Figure 5a. The impact of the herbicide on electron flow and therefore photosynthetic $\mathrm{O}_{2}$ production is confirmed by comparing the steep slope corresponding to oxygen production rate (nA/min) during photosynthesis obtained for the blank algal solution with the smoother one obtained for Diuron contaminated algal solution. It is yet demonstrated that there is no toxicantinduced inhibition on respiration procedure as the two slopes corresponding to oxygen consumption for blank and contaminated algal solution are identical.

Oxygen production rates for different pollutant concentrations $(0.2-1 \mu \mathrm{M})$ were compared in order to demonstrate concentration dependent inhibition effect of the herbicide on 
photosynthesis (Figure 5b). The response of a blank algae solution was first compared to the one of an algal solution with ethanol to validate that ethanol has no inhibitory effect on $\mathrm{O}_{2}$ production. Oxygen production rate obtained with our Pt Bl ultramicroelectrode array (25 disks of diameter $\mathrm{d}=10 \mu \mathrm{m}$ ) for a blank algae solution (given strain: Chlamydomonas reinhardtii with a concentration $6 * 10^{6}$ cells $/ \mathrm{mL}$ ) is $10 \mathrm{nA} / \mathrm{min}$. We then compared the latter rate to the rate obtained for algal solution containing different concentrations of Diuron herbicide. The rate corresponding to the limit of maximum acceptable concentration of this pollutant implemented by governments $(0.6 \mu \mathrm{M}$ of Diuron) was finally calculated at $4 \mathrm{nA} / \mathrm{min}$.

The inhibition on the oxygen production rate percent induced by herbicides was estimated from the oxygen production rate calculated before and after the herbicide injection and it is defined as followed:

$$
\text { Inhibition ratio } \%=\frac{\text { rate }_{\text {blank }}-\text { rate }_{i}}{\text { rate }_{\text {blank }}}
$$

Where rateblank represents oxygen production rate during photosynthesis for blank algal solution and rate $e_{\text {r }}$ represents the rate for different concentrations of Diuron injected in algal solutions.

The Diuron calibration graph, given in Figure 6, demonstrates that inhibition increases along with Diuron concentration. Variation in production rate obtained was $65 \%$ inhibition per $\mu \mathrm{M}$ of Diuron with LOD of around $0.2 \mu \mathrm{M}$ lower than maximum acceptable concentration in drinking water implemented by European governments $(0.64 \mu \mathrm{M})$. It is therefore demonstrated that the fabricated electrochemical biosensor can be an efficient indicator of water pollution.

Although aforementioned fabricated systems aim for environmental applications that require disposable devices in compliance with regulations, the characteristics of our prototypes were tested in order to examine their reproducibility. The devices were used through several tests with algae and different concentrations of Diuron pollutant without significant variation in their response (around 60 tests with one device). A cleaning step in $0.5 \mathrm{M} \mathrm{H}_{2} \mathrm{SO}_{4}$ before each series of 
measurements was applied in order to reactivate the electrode surface and recycle the system. The stability of the insulation layer that defines active areas as well as the stability of different active electrode layers can thus be validated. We can therefore also target other applications that require repetitive and/or online measurements.

\section{CONCLUSION}

We have presented above the development of a micro-biosensor for the detection of environmental pollution. Electrochemical microcells were fabricated for the detection of $\mathrm{O}_{2}$, $\mathrm{H}_{2} \mathrm{O}_{2}$ and $\mathrm{H}_{3} \mathrm{O}^{+} / \mathrm{OH}^{-}$ions, species taking part in metabolic activities of algae. Electrochemical microcells consist of three integrated electrodes (working, reference, and counter) on silicon chip. Electrode materials were chosen according to the species to be detected: Pt and black Pt electrodes were therefore used for $\mathrm{O}_{2}$ and $\mathrm{H}_{2} \mathrm{O}_{2}$ detection while $\mathrm{W} / \mathrm{WO}_{3}$ and $\mathrm{Pt} / \mathrm{IrO}_{2}$ electrodes were selected for $\mathrm{pH}$ monitoring. Electrodes were characterized, calibrated and further used in bioassays in algal solutions. Given the fact that this paper aims at demonstrating that pollutants' detection can be simply carried out by monitoring changes in algal metabolism induced by presence of herbicides, we firstly focused on $\mathrm{O}_{2}$ monitoring (i.e photosynthetic activity) as indicator of pollution as it is the element the most representative of variations in metabolic activities. $\mathrm{O}_{2}$ evolution was therefore measured in algal solutions and Diuron herbicide detection was achieved with a sufficiently low LOD of $0.2 \mu \mathrm{M}$. However, we also plan to determine in future work the increase in $\mathrm{H}_{2} \mathrm{O}_{2}$ and $\mathrm{OH}^{-}$production caused by presence of herbicides. To the best of our knowledge, the safety level of $\mathrm{H}_{2} \mathrm{O}_{2}$ and $\mathrm{OH}^{-}$in Chlamydomonas reinhardtii algae cells in non-contaminated water is not already determined but it is clearly mentioned that herbicides cause metabolic disruptions resulting in significant increase in the production of ROS (Fedtke and Duke, 2004). Similar to $\mathrm{O}_{2}$ monitoring, the measurement will be conducted by comparing the production of these two species for a blank solution and a herbicide contaminated solution using the $\mathrm{H}_{2} \mathrm{O}_{2}$ and $\mathrm{pH}$ sensors we fabricated that exhibit high sensitivity and 
satisfactory LOD.

These aforesaid results may form the basis for the integration of the three independent $\mu$ electrochemical sensors $\left(\mathrm{O}_{2}, \mathrm{H}_{2} \mathrm{O}_{2}, \mathrm{pH}\right)$ on the same fluidic platform by creating a matrix of channels and measurement chambers for multianalysis. Monitoring of each species can indicate the presence of different herbicides type. Indeed, herbicides like Diuron and Atrazine target Photosystem II, with a direct impact on $\mathrm{O}_{2}$ production, while herbicides like Paraquat target Photosystem I by causing an increase in $\mathrm{H}_{2} \mathrm{O}_{2}$ and $\mathrm{OH}^{-}$production. The detection of the three species can be performed at the same time by integrating each sensor in one independent chamber. A different fluidic chamber should be dedicated for the detection of each species as detection protocols are different: extracellular $\mathrm{O}_{2}$ variation measurement can be directly performed after adding algae cells whereas intracellular $\mathrm{H}_{2} \mathrm{O}_{2}$ and $\mathrm{pH}$ variation monitoring calls for cell lysis prior to measurement. Moreover, dissociation of measurement chambers is important as not only electrochemical methods conducted for detection are different (chronoamperometry or potentiometry) but also detection of one species can produce elements that interfere with the measurement of the other species (i.e $\mathrm{O}_{2}$ reduction produces $\mathrm{H}_{2} \mathrm{O}_{2}$ ).

This final multi-detection structure will be completed by integrating an optical sensor on the same $\mu$ fluidic platform (Lefèvre et al., 2012). Thus, combining amperometric and optical detection, improved sensor's performance towards herbicide detection can be attained.

\section{Acknowledgement}

The authors would like to thank the French "Agence nationale de la Recherche" (ANR, project DOLFIN, n ANR-13-JS03-0005-01). Special thanks should also be addressed to Céline Christophe (LAAS-CNRS), Stephane Arbault, Salem Ben Amor and Damien Quinton of the Institute of Molecular Sciences (ISM, University of Bordeaux) as well as Florent Lefèvre and Annie Chalifour (Department of biological science, UQAM). Furthermore, microfabrication procedure was partly supported by the French RENATECH network. 


\section{References}

Arbault, S., Pantano, P., Jankowski, J.A., Vuillaume, M., Amatore, C., 1995. Monitoring an oxidative stress mechanism at a single human fibroblast. Anal. Chem. 67, 3382-3390.

Barbash, J.E., Thelin, G.P., Kolpin, D.W., Gilliom, R.J., 2001. Major herbicides in ground water: results from the National Water-Quality Assessment. J. Environ. Qual. 30, 831-845.

Ben-Amor, S., Devin, A., Rigoulet, M., Sojic, N., Arbault, S., 2013. Oxygen Plasma Treatment of Platinized Ultramicroelectrodes Increases Sensitivity for Hydrogen Peroxide Detection on Mitochondria. Electroanalysis 25, 656-663. doi:10.1002/elan.201200409

Ben-Amor, S., Vanhove, E., Sékli Belaïdi, F., Charlot, S., Colin, D., Rigoulet, M., Devin, A., Sojic, N., Launay, J., Temple-Boyer, P., Arbault, S., 2014. Enhanced Detection of Hydrogen Peroxide with Platinized Microelectrode Arrays for Analyses of Mitochondria Activities. Electrochimica Acta, BIOELECTROCHEMISTRY 2013 Selection of papers from the 12th ISE Topical Meeting17-21 March 2013, Bochum, Germany 126, 171-178. doi:10.1016/j.electacta.2013.11.104

Ben-Yoav, H., Biran, A., Pedahzur, R., Belkin, S., Buchinger, S., Reifferscheid, G., Shacham-Diamand, Y., 2009. A whole cell electrochemical biosensor for water genotoxicity bio-detection. Electrochimica Acta 54, 6113-6118. doi:10.1016/j.electacta.2009.01.061

Bezbaruah, A.N., Zhang, T.C., 2002. Fabrication of anodically electrodeposited iridium oxide film pH microelectrodes for microenvironmental studies. Anal. Chem. 74, 5726-5733.

Brayner, R., Couté, A., Livage, J., Perrette, C., Sicard, C., 2011. Micro-algal biosensors. Anal. Bioanal. Chem. 401, 581-597. doi:10.1007/s00216-011-5107-z

Brett, A.M.O., Matysik, F.-M., Vieira, M.T., 1997. Thin-film gold electrodes produced by magnetron sputtering. Voltammetric characteristics and application in batch injection analysis with amperometric detection. Electroanalysis 9, 209-212. doi:10.1002/elan.1140090304

Carrilho, E.N.V.M., Nóbrega, J.A., Gilbert, T.R., 2003. The use of silica-immobilized brown alga (Pilayella littoralis) for metal preconcentration and determination by inductively coupled plasma optical emission spectrometry. Talanta 60, 11311140. doi:10.1016/S0039-9140(03)00217-0

Chan, C., Lehmann, M., Chan, K., Chan, P., Chan, C., Gruendig, B., Kunze, G., Renneberg, R., 2000. Designing an amperometric thick-film microbial BOD sensor. Biosens. Bioelectron. 15, 343-353. doi:10.1016/S0956-5663(00)00090-7

Cho, S.-H., Jang, A., Bishop, P.L., Moon, S.-H., 2010. Kinetics determination of electrogenerated hydrogen peroxide ( $\mathrm{H} 2 \mathrm{O} 2)$ using carbon fiber microelectrode in electroenzymatic degradation of phenolic compounds. J. Hazard. Mater. 175, 253-257. doi:10.1016/j.jhazmat.2009.09.157

Chouteau, C., Dzyadevych, S., Chovelon, J.-M., Durrieu, C., 2004. Development of novel conductometric biosensors based on immobilised whole cell Chlorella 
vulgaris microalgae. Biosens. Bioelectron. 19, 1089-1096.

doi:10.1016/j.bios.2003.10.012

Chouteau, C., Dzyadevych, S., Durrieu, C., Chovelon, J.-M., 2005. A bi-enzymatic whole cell conductometric biosensor for heavy metal ions and pesticides detection in water samples. Biosens. Bioelectron. 21, 273-281. doi:10.1016/j.bios.2004.09.032

Christophe, C., Sékli Belaidi, F., Launay, J., Gros, P., Questel, E., Temple-Boyer, P., 2013. Elaboration of integrated microelectrodes for the detection of antioxidant species. Sens. Actuators B Chem. 177, 350-356. doi:10.1016/j.snb.2012.11.032

Daomin Zhou, D., 2008. Chapter 10 - Microelectrodes for in-vivo determination of $\mathrm{pH}$, in: Zhang, X., Ju, H., Wang, J. (Eds.), Electrochemical Sensors, Biosensors and Their Biomedical Applications. Academic Press, San Diego, pp. 261-305.

De Corcuera, J.I.R., R.P. Cavalieri, Powers, J.R., 2005. Improved platinization conditions produce a 60 -fold increase in sensitivity of amperometric biosensors using glucose oxidase immobilized in poly-o-phenylenediamine. J. Electroanal. Chem. 575, 229-241. doi:10.1016/j.jelechem.2004.09.015

Dimitrakopoulos, L.T., Dimitrakopoulos, T., Alexander, P.W., Logic, D., Hibbert, D.B., 1998. A tungsten oxide coated wire electrode used as a $\mathrm{pH}$ sensor in flow injection potentiometry. Anal. Commun. 35, 395-398. doi:10.1039/A807697I

Eltzov, E., Marks, R.S., 2011. Whole-cell aquatic biosensors. Anal. Bioanal. Chem. 400, 895-913. doi:10.1007/s00216-010-4084-y

Fedtke, C., Duke, S., 2004. Plant Toxicology, Fourth Edition.

Gaberlein, S., Spener, F., Zaborosch, C., 2000. Microbial and cytoplasmic membranebased potentiometric biosensors for direct determination of organophosphorus insecticides. Appl. Microbiol. Biotechnol. 54, 652-658. doi: $10.1007 / \mathrm{s} 002530000437$

Ges, I.A., Ivanov, B.L., Schaffer, D.K., Lima, E.A., Werdich, A.A., Baudenbacher, F.J., 2005. Thin-film IrOx pH microelectrode for microfluidic-based microsystems. Biosens. Bioelectron. 21, 248-256. doi:10.1016/j.bios.2004.09.021

Giardi, M.T., Pace, E., 2005. Photosynthetic proteins for technological applications. Trends Biotechnol. 23, 257-263. doi:10.1016/j.tibtech.2005.03.003

Grieshaber, D., MacKenzie, R., Vörös, J., Reimhult, E., 2008. Electrochemical Biosensors - Sensor Principles and Architectures. Sensors 8, 1400-1458. doi: $10.3390 / \mathrm{s} 8031400$

Han, T., 2002. Flow injection microbial trichloroethylene sensor. Talanta 57, 271-276. doi:10.1016/S0039-9140(02)00027-9

Huang, W.-D., Cao, H., Deb, S., Chiao, M., Chiao, J.C., 2011. A flexible pH sensor based on the iridium oxide sensing film. Sens. Actuators Phys. 169, 1-11. doi:10.1016/j.sna.2011.05.016

Ikebukuro, K., Honda, M., Nakanishi, K., Nomura, Y., Masuda, Y., Yokoyama, K., Yamauchi, Y., Karube, I., 1996. Flow-type cyanide sensor using an immobilized microorganism. Electroanalysis 8, 876-879. doi:10.1002/elan.1140081005

Jaffrezic-Renault, N., Dzyadevych, S.V., 2008. Conductometric Microbiosensors for Environmental Monitoring. Sensors 8, 2569-2588. doi:10.3390/s8042569

Jang, A., Zou, Z., Lee, K.K., Ahn, C.H., Bishop, P.L., 2011. State-of-the-art lab chip sensors for environmental water monitoring. Meas. Sci. Technol. 22, 032001. doi:10.1088/0957-0233/22/3/032001

Jáuregui, O., Moyano, E., Galceran, M.T., 1997. Liquid chromatography-atmospheric pressure ionization mass spectrometry for the determination of chloro- and 
nitrophenolic compounds in tap water and sea water. J. Chromatogr. A 787, 7989. doi:10.1016/S0021-9673(97)00653-5

Karyakin, A.A., Kuritsyna, E.A., Karyakina, E.E., Sukhanov, V.L., 2009. Diffusion controlled analytical performances of hydrogen peroxide sensors: Towards the sensor with the largest dynamic range. Electrochimica Acta 54, 5048-5052. doi:10.1016/j.electacta.2008.11.049

Kasai, F., Hatakeyama, S., 1993. Herbicide susceptibility in two green algae, Chlorella vulgaris and Selenastrum capricornutum. Chemosphere 27, 899-904. doi:10.1016/0045-6535(93)90019-2

Kim, T.Y., Yang, S., 2014. Fabrication method and characterization of electrodeposited and heat-treated iridium oxide films for $\mathrm{pH}$ sensing. Sens. Actuators B Chem. 196, 31-38. doi:10.1016/j.snb.2014.02.004

Konopka, S.J., McDuffie, B., 1970. Diffusion coefficients of ferri- and ferrocyanide ions in aqueous media, using twin-electrode thin-layer electrochemistry. Anal. Chem. 42, 1741-1746. doi:10.1021/ac50160a042

Lagarde, F., Jaffrezic-Renault, N., 2011. Cell-based electrochemical biosensors for water quality assessment. Anal. Bioanal. Chem. 400, 947-964. doi:10.1007/s00216-011-4816-7

Lawrence, A.J., Moores, G.R., 1972. Conductimetry in Enzyme Studies. Eur. J. Biochem. 24, 538-546. doi:10.1111/j.1432-1033.1972.tb19716.x

Lee, J.-H., Lim, T.-S., Seo, Y., Bishop, P.L., Papautsky, I., 2007. Needle-type dissolved oxygen microelectrode array sensors for in situ measurements. Sens. Actuators B Chem. 128, 179-185. doi:10.1016/j.snb.2007.06.008

Lee, Y.J., Park, J.Y., 2011. A Highly Miniaturized Dissolved Oxygen Sensor Using a Nanoporous Platinum Electrode Electroplated on Silicon. J. Korean Phys. Soc. 58, 1505. doi:10.3938/jkps.58.1505

Lefèvre, F., Chalifour, A., Yu, L., Chodavarapu, V., Juneau, P., Izquierdo, R., 2012. Algal fluorescence sensor integrated into a microfluidic chip for water pollutant detection. Lab. Chip 12, 787. doi:10.1039/c2lc20998e

Lehmann, M., Riedel, K., Adler, K., Kunze, G., 2000. Amperometric measurement of copper ions with a deputy substrate using a novel Saccharomyces cerevisiae sensor. Biosens. Bioelectron. 15, 211-219. doi:10.1016/S0956-5663(00)00060-9

Lei, Y., Chen, W., Mulchandani, A., 2006. Microbial biosensors. Anal. Chim. Acta 568, 200-210. doi:10.1016/j.aca.2005.11.065

Li, Y., Sella, C., Lemaître, F., Guille Collignon, M., Thouin, L., Amatore, C., 2013. Highly Sensitive Platinum-Black Coated Platinum Electrodes for Electrochemical Detection of Hydrogen Peroxide and Nitrite in Microchannel. Electroanalysis 25, 895-902. doi:10.1002/elan.201200456

Liu, S.-Y., Liu, G., Tian, Y.-C., Chen, Y.-P., Yu, H.-Q., Fang, 2007. An Innovative Microelectrode Fabricated Using Photolithography for Measuring Dissolved Oxygen Distributions in Aerobic Granules. Environ. Sci. Technol. 41, 5447-5452. doi:10.1021/es070532g

MAJA N. DESIC, M.M.P., 2005. Study of gold-platinum and platinum-gold surface modification and its influence on hydrogen evolution and oxygen reduction. J. Serbian Chem. Soc.

Marzouk, S.A., Ufer, S., Buck, R.P., Johnson, T.A., Dunlap, L.A., Cascio, W.E., 1998. Electrodeposited iridium oxide $\mathrm{pH}$ electrode for measurement of extracellular myocardial acidosis during acute ischemia. Anal. Chem. 70, 5054-5061.

Marzouk, S.A.M., 2003. Improved electrodeposited iridium oxide $\mathrm{pH}$ sensor fabricated on etched titanium substrates. Anal. Chem. 75, 1258-1266. 
Mittler, R., 2002. Oxidative stress, antioxidants and stress tolerance. Trends Plant Sci. 7, 405-410. doi:10.1016/S1360-1385(02)02312-9

Mittler, R., Vanderauwera, S., Gollery, M., Van Breusegem, F., 2004. Reactive oxygen gene network of plants. Trends Plant Sci. 9, 490-498.

doi:10.1016/j.tplants.2004.08.009

Moreno-Garrido, I., 2008. Microalgae immobilization: Current techniques and uses. Bioresour. Technol. 99, 3949-3964. doi:10.1016/j.biortech.2007.05.040

Mulchandani, A., Chen, W., Mulchandani, P., Wang, J., Rogers, K.R., 2001. Biosensors for direct determination of organophosphate pesticides. Biosens. Bioelectron. 16, 225-230. doi:10.1016/S0956-5663(01)00126-9

Mulchandani, P., Hangarter, C.M., Lei, Y., Chen, W., Mulchandani, A., 2005.

Amperometric microbial biosensor for $\mathrm{p}$-nitrophenol using Moraxella sp.-modified carbon paste electrode. Biosens. Bioelectron. 21, 523-527.

doi:10.1016/j.bios.2004.11.011

N Sueoka, K.S.C., 1967. Deoxyribonucleic acid replication in meiosis of Chlamydomonas reinhardi. I. Isotopic transfer experiments with a strain producing eight zoospores. J. Mol. Biol. 25, 47-66. doi:10.1016/0022-2836(67)90278-1

Nowall, W.B., Kuhr, W.G., 1997. Detection of hydrogen peroxide and other molecules of biologicl importance at an electrocataltic surface on a carbon fiber microelectrode. Electroanalysis 9, 102-109. doi:10.1002/elan.1140090203

Olthuis, W., Robben, M.A.M., Bergveld, P., Bos, M., van der Linden, W.E., 1990. pH sensor properties of electrochemically grown iridium oxide. Sens. Actuators $B$ Chem. 2, 247-256. doi:10.1016/0925-4005(90)80150-X

Pandard, P., Rawson, D.M., 1993. An amperometric algal biosensor for herbicide detection employing a carbon cathode oxygen electrode. Environ. Toxicol. Water Qual. 8, 323-333. doi:10.1002/tox.2530080309

Pasti, I.A., Lazarevic-Pasti, T., Mentus, S.V., 2012. Switching between voltammetry and potentiometry in order to determine $\mathrm{H}+$ or $\mathrm{OH}$ - ion concentration over the entire pH scale by means of tungsten disk electrode. J. Electroanal. Chem. 665, 83-89. doi:10.1016/j.jelechem.2011.11.019

Pereira Rodrigues, N., Sakai, Y., Fujii, T., 2008. Cell-based microfluidic biochip for the electrochemical real-time monitoring of glucose and oxygen. Sens. Actuators $B$ Chem. 132, 608-613. doi:10.1016/j.snb.2007.12.025

Pfister, K., Steinback, K.E., Gardner, G., Arntzen, C.J., 1981. Photoaffinity labeling of an herbicide receptor protein in chloroplast membranes. Proc. Natl. Acad. Sci. U. S. A. 78, 981-985.

Qiang, L., Vaddiraju, S., Rusling, J.F., Papadimitrakopoulos, F., 2010. Highly sensitive and reusable Pt-black microfluidic electrodes for long-term electrochemical sensing. Biosens. Bioelectron. 26, 682-688. doi:10.1016/j.bios.2010.06.064

Ruffien-Ciszak, A., Baur, J., Gros, P., Questel, E., Comtat, M., 2008. Electrochemical microsensors for cutaneous surface analysis: Application to the determination of $\mathrm{pH}$ and the antioxidant properties of stratum corneum. IRBM 29, 162-170. doi:10.1016/j.rbmret.2007.11.020

Ruzgas, T., Csöregi, E., Emnéus, J., Gorton, L., Marko-Varga, G., 1996. Peroxidasemodified electrodes: Fundamentals and application. Anal. Chim. Acta 330, 123138. doi:10.1016/0003-2670(96)00169-9

Saito, Y., 1968. A Theoretical Study on the Diffusion Current at the Stationary Electrodes of Circular and Narrow Band Types. Rev. Polarogr. 15, 177-187.

Schellin, M., Hauser, B., Popp, P., 2004. Determination of organophosphorus pesticides using membrane-assisted solvent extraction combined with large volume 
injection-gas chromatography-mass spectrometric detection. J. Chromatogr. A $1040,251-258$.

Schubnell, D., Lehmann, M., Baumann, W., Rott, F.G., Wolf, B., Beck, C.F., 1999. An ISFET-algal (Chlamydomonas) hybrid provides a system for eco-toxicological tests. Biosens. Bioelectron. 14, 465-472. doi:10.1016/S0956-5663(99)00025-1

Shitanda, I., Takamatsu, S., Watanabe, K., Itagaki, M., 2009. Amperometric screenprinted algal biosensor with flow injection analysis system for detection of environmental toxic compounds. Electrochimica Acta 54, 4933-4936. doi:10.1016/j.electacta.2009.04.005

Simonis, A., Lüth, H., Wang, J., Schöning, M.J., 2004. New concepts of miniaturised reference electrodes in silicon technology for potentiometric sensor systems. Sens. Actuators B Chem. 103, 429-435. doi:10.1016/j.snb.2004.04.072

Sosna, M., Denuault, G., Pascal, R.W., Prien, R.D., Mowlem, M., 2007. Development of a reliable microelectrode dissolved oxygen sensor. Sens. Actuators B Chem. 123, 344-351. doi:10.1016/j.snb.2006.08.033

Tilak, B.V., Conway, B.E., Angerstein-Kozlowska, H., 1973. The real condition of oxidized pt electrodes: Part III. Kinetic theory of formation and reduction of surface oxides. J. Electroanal. Chem. Interfacial Electrochem. 48, 1-23. doi:10.1016/S0022-0728(73)80290-6

Tischer, W., Strotmann, H., 1977. Relationship between inhibitor binding by chloroplasts and inhibition of photosynthetic electron transport. Biochim. Biophys. Acta BBA - Bioenerg. 460, 113-125. doi:10.1016/0005-2728(77)901578

Vaddiraju, S., Tomazos, I., Burgess, D.J., Jain, F.C., Papadimitrakopoulos, F., 2010. Emerging synergy between nanotechnology and implantable biosensors: A review. Biosens. Bioelectron. 25, 1553-1565. doi:10.1016/j.bios.2009.12.001

Vanhove, E., Tsopéla, A., Bouscayrol, L., Desmoulin, A., Launay, J., Temple-Boyer, P., 2013. Final capping passivation layers for long-life microsensors in real fluids. Sens. Actuators B Chem. 178, 350-358. doi:10.1016/j.snb.2012.12.088

Varsamis, D.G., Touloupakis, E., Morlacchi, P., Ghanotakis, D.F., Giardi, M.T., Cullen, D.C., 2008. Development of a photosystem II-based optical microfluidic sensor for herbicide detection. Talanta 77, 42-47. doi:10.1016/j.talanta.2008.05.060

Wittkampf, M., Chemnitius, G.-C., Cammann, K., Rospert, M., Mokwa, W., 1997. Silicon thin film sensor for measurement of dissolved oxygen. Sens. Actuators B Chem. 43, 40-44. doi:10.1016/S0925-4005(97)00138-X

Yamamoto, K., Shi, G., Zhou, T., Xu, F., Zhu, M., Liu, M., Kato, T., Jin, J.-Y., Jin, L., 2003. Solid-state $\mathrm{pH}$ ultramicrosensor based on a tungstic oxide film fabricated on a tungsten nanoelectrode and its application to the study of endothelial cells. Anal. Chim. Acta 480, 109-117. doi:10.1016/S0003-2670(02)01602-1

Yokoyama, H., Tsuchihashi, N., Kasai, N., Matsue, T., Uchida, I., Mori, N., OhyaNishiguchi, H., Kamada, H., 1997. Hydrogen peroxide augmentation in a rat striatum after methamphetamine injection as monitored in vivo by a Pt-disk microelectrode. Biosens. Bioelectron. 12, 1037-1041.

Zhang, Y., Wilson, G.S., 1993. Electrochemical oxidation of H2O2 on Pt and Pt + Ir electrodes in physiological buffer and its applicability to $\mathrm{H} 2 \mathrm{O} 2$-based biosensors. J. Electroanal. Chem. 345, 253-271. doi:10.1016/0022-0728(93)80483-X 


\section{Figures caption}

Figure 1. (a)_Schematic representation of all layers comprising the fabricated electrochemical sensor (b) Autonomous electrochemical micro-sensor.

Figure 2. (a) Current measurement after successive injections of $\mathrm{H}_{2} \mathrm{O}_{2}$ for a $\mathrm{Pt} \mathrm{Bl}$ array electrode. The potential applied is $0.3 \mathrm{~V}$ vs $\mathrm{Ag} / \mathrm{AgCl} / \mathrm{KCl}_{\text {sat }}$ Inset: Current response for $10 \mathrm{nM} \mathrm{H}_{2} \mathrm{O}_{2}$ injection. (b) $\mathrm{H}_{2} \mathrm{O}_{2}$ calibration curves obtained for $\mathrm{Pt} \mathrm{BI}$ and $\mathrm{Pt}$ single electrodes and arrays.

Figure 3. $\mathrm{pH}$ monitoring with $\mathrm{OCP}$ measurement. a) $\mathrm{IrO}_{2}$ response for different $\mathrm{pH}$ values, b) Calibration curves for $\mathrm{IrO}_{2}$ and $\mathrm{W} \mathrm{WO}_{3}$ electrodes.

Figure 4. Current measurement through algal respiration and photosynthesis with $\mathrm{Pt} \mathrm{Bl}$ array electrode

Figure 5. Algal response to (a) $0.5 \mu \mathrm{M}$ Diuron herbicide (b) various Diuron concentrations for $\mathrm{Pt} \mathrm{BI}$ array electrode

Figure 6. Calibration curves (inhibition percent in oxygen production rate during photosynthesis versus Diuron concentration) for $\mathrm{Pt} \mathrm{Bl}$ array electrode. 
a)

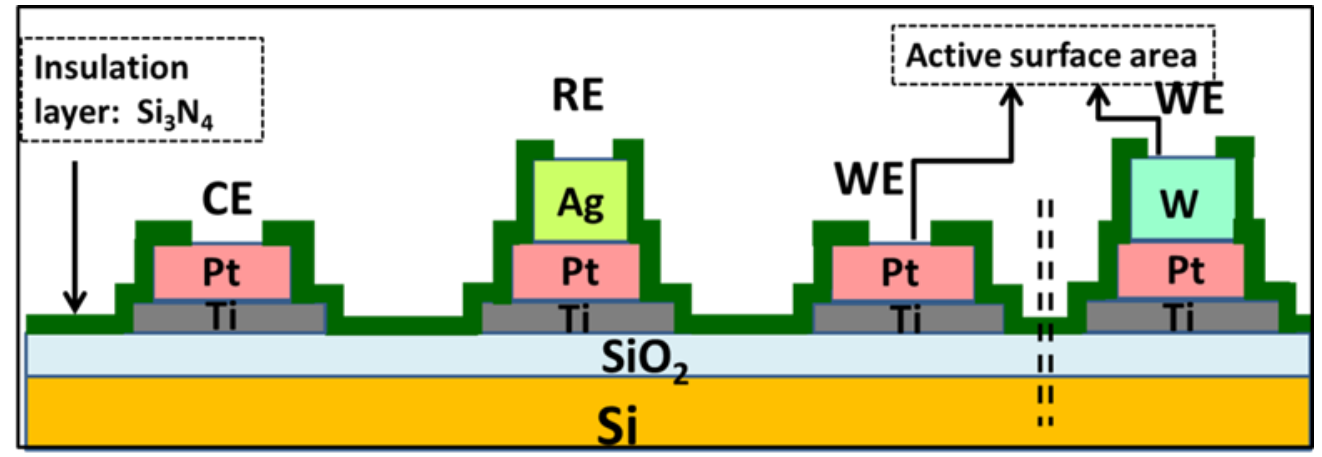

b)

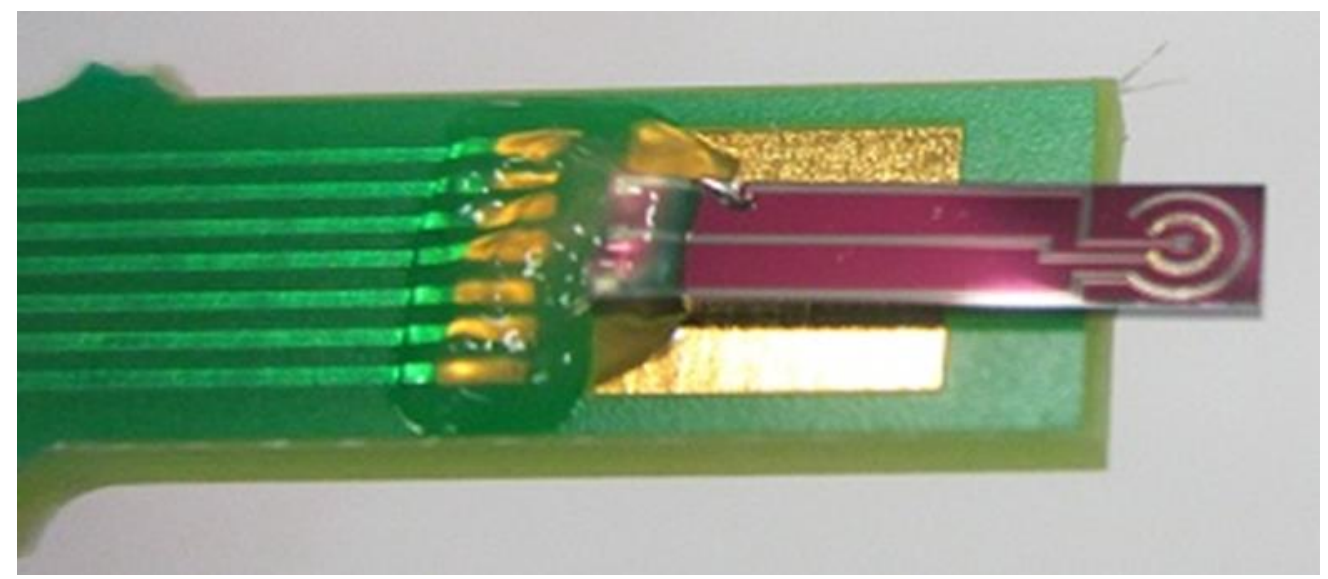

Figure 1. (a) Schematic representation of all layers comprising the fabricated electrochemical sensor (b) Autonomous electrochemical micro-sensor. 
a)

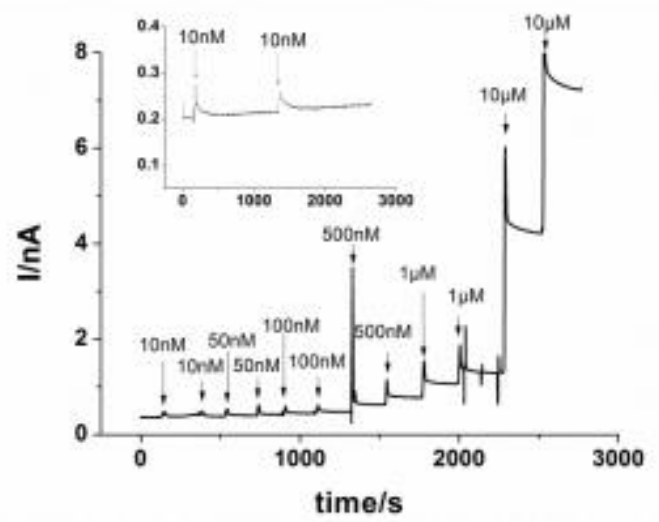

b)

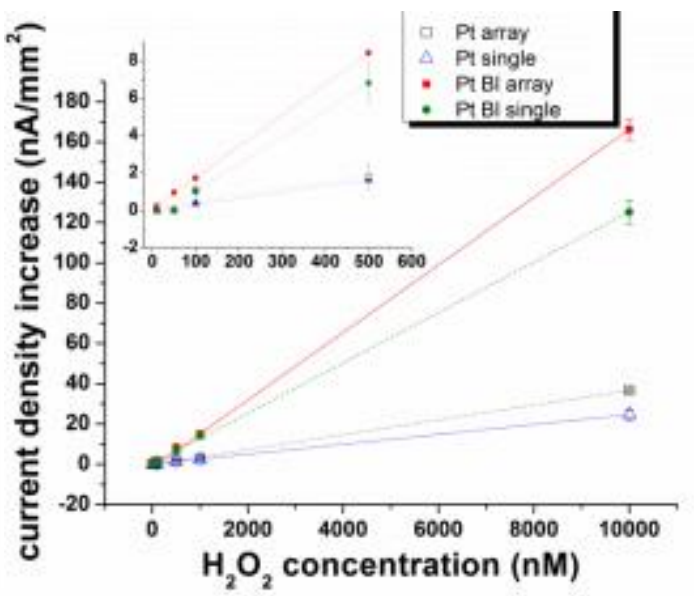

Figure 2. (a) Current measurement after successive injections of $\mathrm{H}_{2} \mathrm{O}_{2}$ for a $\mathrm{Pt} \mathrm{Bl}$ array electrode. The potential applied is $0.3 \mathrm{~V}$ vs Ag/AgCl/KClsat Inset: Current response for $10 \mathrm{nM} \mathrm{H}_{2} \mathrm{O}_{2}$ injection. (b) $\mathrm{H}_{2} \mathrm{O}_{2}$ calibration curves obtained for $\mathrm{Pt} \mathrm{BI}$ and Pt single electrodes and arrays. 
a)

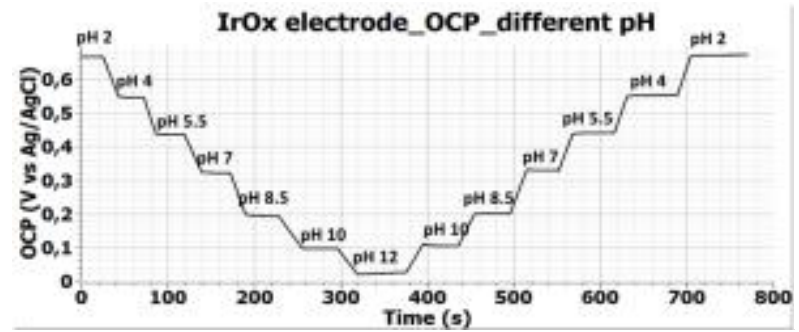

b)

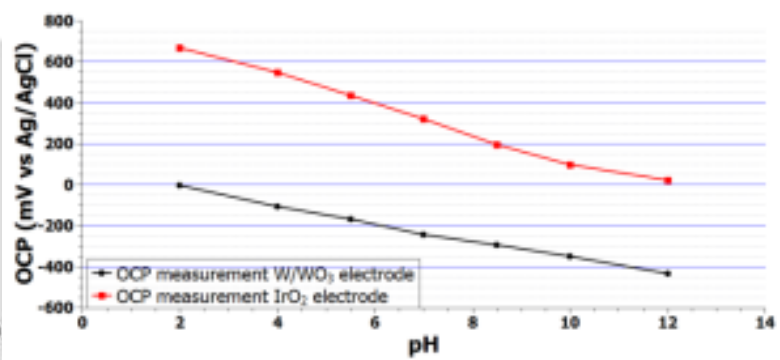

Figure 3. $\mathrm{pH}$ monitoring with $\mathrm{OCP}$ measurement. a) $\mathrm{IrO}_{2}$ response for different $\mathrm{pH}$ values, b) Calibration curves for $\mathrm{IrO}_{2}$ and $\mathrm{W}_{\mathrm{WO}}$ electrodes. 


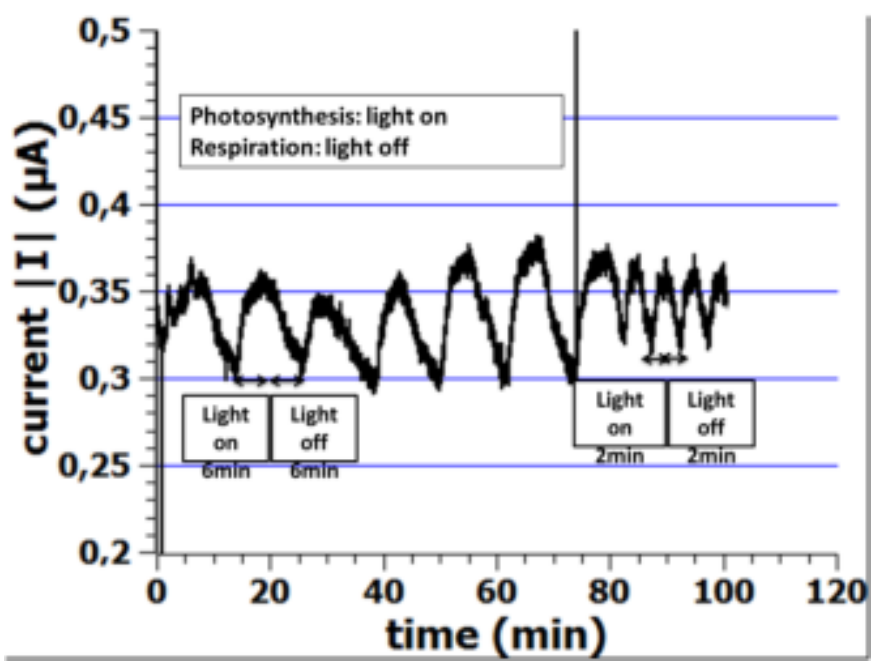

Figure 4. Current measurement through algal respiration and photosynthesis with $\mathrm{Pt} \mathrm{Bl}$ array electrode. 
a)

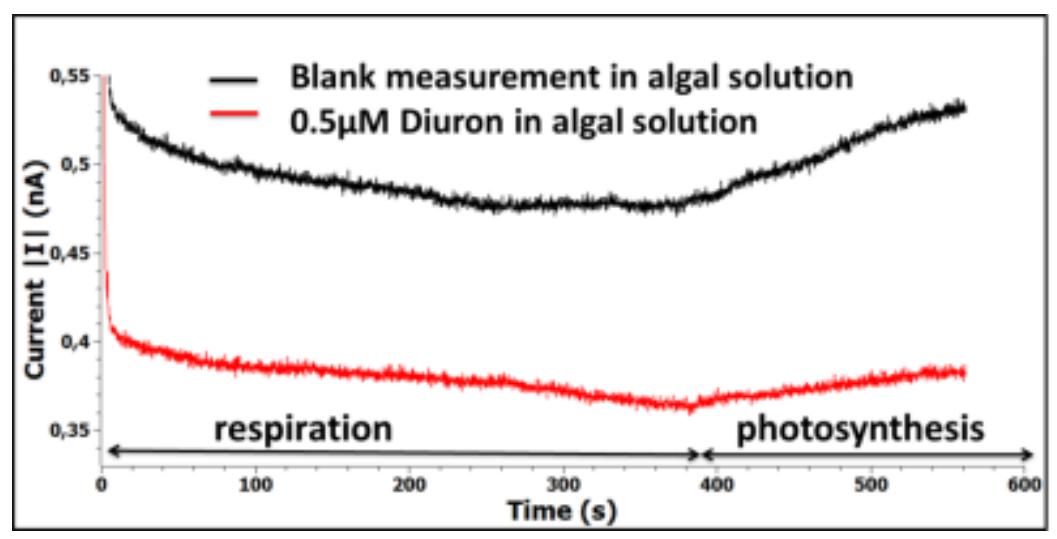

b)

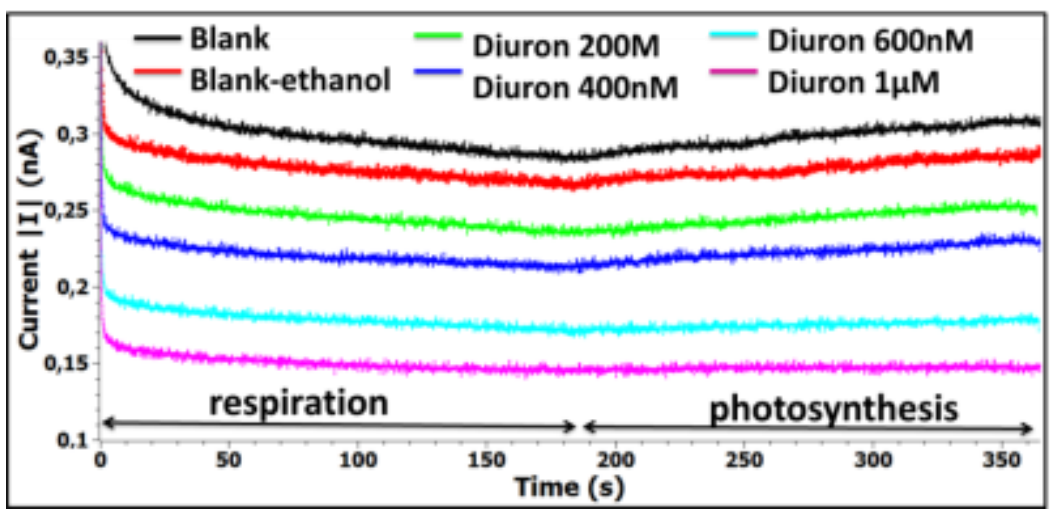

Figure 5. Algal response to (a) $0.5 \mu \mathrm{M}$ Diuron herbicide (b) various Diuron concentrations for Pt $\mathrm{BI}$ array electrode. 


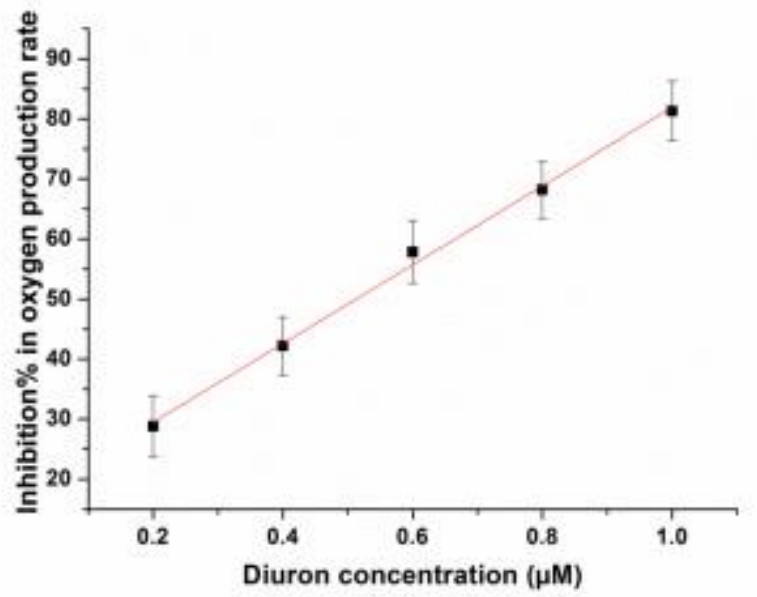

Figure 6. Calibration curves (inhibition percent in oxygen production rate during photosynthesis versus Diuron concentration) for $\mathrm{Pt} \mathrm{Bl}$ array electrode. 